Quality : Jurnal Kesehatan

Volume 14, Nomor 1 Tahun 2020

pISSN : 1978-4325, eISSN : 2655-2434, DOI: $10.36082 / q j k . v 14 i 1.96$

\title{
MODEL 5DAYS GOSGI SEBAGAI UPAYA PEMBENTUKAN KEMANDIRIAN MENGGOSOK GIGI ANAK USIA DINI DI SEKOLAH
}

\begin{tabular}{|c|c|}
\hline Info Artikel & Abstrak \\
\hline $\begin{array}{l}\text { Genesis Naskah: } \\
\text { Submissions: } 17-3- \\
2020 \\
\text { Revised: } \\
\text { 1-4-2020, 20-5-2020. } \\
\text { Accepted: } 25-5-2020\end{array}$ & $\begin{array}{l}\text { Masalah kesehatan gigi dan mulut yang banyak diderita masyarakat Indonesia adalah karies gigi dan } \\
\text { penyakit periodontal, dimana prevalensi karies gigi anak usia 5-6 tahun sebesar } 93 \% \text { dengan indeks def-t } \\
\text { 8,43. Kondisi tersebut belum memenuhi target WHO dan FDI yaitu 50\% anak usia 5-6 tahun bebas dari } \\
\text { karies gigi. Hal ini disebabkan karena anak belum mampu melakukan aktivitas mandiri dalam menggosok } \\
\text { gigi. Model 5Days gosgi merupakan upaya pembelajaran menggosok gigi dalam upaya pembentukan } \\
\text { kemandirian menggosok gigi pada anak usia dini yang dilakukan di sekolah. Penelitian ini bertujuan untuk } \\
\text { efektivitas model 5Days gosgi sebagai upaya pembentukan kemandirian menggosok gigi serta } \\
\text { meningkatkan status kebersihan gigi dan mulut anak usia dini di sekolah. Metode: penelitian ini } \\
\text { menggunakan quasy experiment dengan rancangan pretest and posttest with one group design. Penelitian } \\
\text { ini dilakukan di TK di wilayah Pondok Labu Cilandak Jakarta Selatan. Variabel bebas: penerapan model } \\
\text { 5Days gosgi dan variabel terikat: kemandirian menggosok gigi dan status kebersihan gigi dan mulut anak } \\
\text { usia dini. Data diuji menggunakan wilcoxon. Hasil: penerapan model 5Days gosgi efektif meningkatkan } \\
\text { kemandirian menggosok gigi (p<0.001) dan efektif terhadap peningkatan status kebersihan gigi dan mulut } \\
\text { anak usia dini (p<0.001). Kesimpulan: Model 5Days gosgi efektif sebagai pembentukan kemandirian } \\
\text { menggosok gigi anak usia dini di sekolah. }\end{array}$ \\
\hline
\end{tabular}

\section{THE 5DAYS GOSGI MODEL AS AN EFFORTS FOR ESTABLISHMENT OF INDEPENDENCE IN BRUSHING TEETH EARLY CHILDHOOD AT SCHOOL}

\author{
Keywords: \\ 5Days Gosgi, \\ Independence, \\ Brushing Teeth
}

\begin{abstract}
Oral health problems that many have encountered are dental caries and periodontal disease where the prevalence of dental caries of children aged 5-6 years by $93 \%$ with def-t index of 8.43 . Such conditions do not meet the WHO target and FDI is 50\% of children aged 5-6 years free of dental caries, it is because children are not capable of independent activity in brushing teeth. The 5Days gosgi model is an effort to learn to brush teeth in an effort to establish independence in brushing their teeth at an early age at school. This study aims to the effectiveness of the 5Days gosgi model as an effort to establish the independence of brushing teeth and to improve the status of oral hygiene in early childhood at school. Method: this study used a quasy experiment with a pretest and posttest with one group design. This research was conducted in kindergarten in Pondok Labu Cilandak, South Jakarta. Independent variable: the application of the 5Days gosgi model and the dependent variable: independence of brushing teeth and the oral hygiene status of early childhood. Data were tested using Wilcoxon. Results: The application of the 5Days gosgi model effectively increased the independence of brushing $(p<0.001)$ and was effective in improving the oral hygiene status of early childhood ( $p<0.001$ ). Conclusion: 5Days gosgi model is effective as the formation of independence in brushing teeth in early childhood at school.
\end{abstract}

\section{Korespondensi Penulis:}

Tedi Purnama,

Jurusan Keperawatan Gigi, Politeknik Kesehatan Jakarta I

email: jkg_jakartal@yahoo.com

(C) Poltekkes Kemenkes Jakarta I

ISSN 2655-2434

Jl. Wijaya Kusuma No. 47-48 Cilandak Jakarta Selatan, Indonesia

email: jurnalquality@poltekkesjakarta1.ac.id 


\section{Pendahuluan}

Pembangunan di bidang kesehatan gigi merupakan bagian integral dari pembangunan kesehatan secara umum (Alhamda, 2011). UndangUndang Nomor 36 Tahun 2009 tentang Kesehatan pasal 93 dan 94, dinyatakan bahwa pelayanan kesehatan gigi dan mulut dilakukan untuk memelihara dan meningkatkan derajat kesehatan masyarakat dalam bentuk peningkatan kesehatan gigi, pencegahan penyakit gigi, pengobatan penyakit gigi, dan pemulihan kesehatan gigi yang dilakukan secara terpadu, terintegrasi dan berkesinambungan dan dilaksanakan melalui pelayanan kesehatan gigi perseorangan, pelayanan kesehatan gigi masyarakat, usaha kesehatan gigi sekolah, serta pemerintah dan pemerintah daerah wajib menjamin ketersediaan tenaga, fasilitas pelayanan, alat dan obat kesehatan gigi dan mulut dalam rangka memberikan pelayanan kesehatan gigi dan mulut yang aman, bermutu, dan terjangkau oleh masyarakat (Kemenkes, 2012).

Masalah kesehatan gigi yang banyak diderita masyarakat Indonesia adalah karies gigi. (Notohartojo, 2011). Penyakit karies gigi merupakan suatu proses demineralisasi struktur jaringan keras gigi seperti dentin dan enamel. Karies gigi atau gigi berlubang merupakan masalah kesehatan gigi dan mulut yang sering dialami oleh hampir seluruh masyarakat di Indonesia (Sosiawan, 2015). Hal ini dibuktikan Riset Kesehatan Dasar tahun 2018 melaporkan anak usia 5-6 tahun mengalami masalah kesehatan gigi sebesar 93\% dengan angka def-t nasional 8,43 artinya rata-rata jumlah kerusakan gigi sebesar 8 sampai 9 gigi setiap anak. Kondisi tersebut belum memenuhi target WHO dan FDI yaitu 50\% anak usia 5-6 tahun bebas dari karies gigi (Riskesdas, 2018).

Karies gigi pada masa kanak-kanak dapat mengganggu sistem pengunyahan dan mengganggu sistem pencernaan sehingga dapat mengganggu kesehatan dan tumbuh kembang anak (Dogar, 2011). Menurut Kwan dalam Santoso (2017),

(C) Poltekkes Kemenkes Jakarta I

Jl. Wijaya Kusuma No. 47-48 Cilandak Jakarta Selatan, Indonesia email: jurnalquality@poltekkesjakarta1.ac.id lebih dari 50 juta jam sekolah pertahun hilang sebagai akibat yang ditimbulkan oleh sakit gigi pada anak-anak yang berdampak hingga kehidupan dewasa nanti, artinya karies gigi pada masa prasekolah sangat mempengaruhi kualitas hidup anak-anak dan tumbuh kembang.

Tingginya angka penyakit gigi dan mulut saat ini sangat dipengaruhi oleh beberapa faktor yang salah satunya adalah faktor perilaku masyarakat yang belum menyadari pentingnya pemeliharaan kesehatan gigi dan mulut (Pullishery, 2013). Hal ini terlihat bahwa perilaku menyikat gigi penduduk umur $\geq 3$ tahun sebesar $2,8 \%$ yang berperilaku menyikat gigi dengan benar (Riskesdas, 2018). Upaya mencegah terjadinya karies gigi dapat dilakukan melalui perilaku pemeliharaan gigi yang paling utama dan dianjurkan dengan cara melakukan gosok gigi. Menggosok gigi yaitu tindakan sederhana menghilangkan plak dan sisa makanan dengan sikat dan pasta gigi, karena plak dan sisa makanan merupakan penyebab utama terjadinya karies gigi, oleh karena itu diperlukan pembentukan kebiasaan menggosok gigi sejak usia dini. Penelitian Purnama dkk (2019) membuktikan bahwa anak usia dini belum memiliki kemandirian dalam menggosok gigi. Anak usia dini yang tidak mandiri menggosok gigi memiliki status kebersihan gigi yang lebih buruk dibandingkan dengan yang sudah mandiri (Ngatemi, 2020).

Kemandirian anak salah satunya dapat dilihat melalui kegiatan sehari-hari yaitu menanamkan kemandirian pada anak usia dini dilakukan melalui kebersihan. Kemandirian anak usia dini dapat dilakukan seperti menggosok gigi sendiri. Pembentukan kemandirian menggosok gigi pada anak harus dilakukan dalam kehidupan sehari-hari tanpa ada perasaan terpaksa (Nuraini, 2015). Kemampuan menggosok gigi secara baik dan benar merupakan faktor yang cukup penting untuk perawatan kesehatan gigi dan mulut anak usia dini (Arianto, 2014). 
Anak usia dini merupakan "golden age period", artinya masa emas untuk seluruh aspek perkembangan manusia, baik fisik, kognisi emosi maupun sosial, dimana perkembangan kecerdasan pada masa ini mengalami peningkatan sampai $50 \%$. Usia dini merupakan saat ideal untuk melatih kemampuan motorik seorang anak termasuk menggosok gigi, sehingga akan menimbulkan rasa tanggung jawab akan kebersihan dirinya sendiri (Martani, 2012).

Model 5days gosgi merupakan metode yang dikembangkan untuk menciptakan kemandirian menggosok gigi setiap hari di sekolah. Hal ini berbeda dengan metode yang umumnya dilakukan tenaga kesehatan gigi yaitu penyuluhan kesehatan gigi dan sikat gigi bersama. Kelebihan metode ini yaitu dapat membentuk kemandirian menggosok gigi di sekolah dalam waktu yang relatif singkat (5 hari). Dengan penerapan menggosok gigi setiap hari disekolah efektif meningkatkan keterampilan menggosok gigi dan status kebersihan gigi anak prasekolah (Purnama dkk, 2019). Penelitian Arum (2016) juga membuktikan bahwa kegiatan menggosok gigi mampu meningkatkan minat anak dalam kemampuan bina diri dalam aspek menggosok gigi.

Pelaksanaan model 5Days gosgi dilakukan pada Lembaga Pendidikan anak usia dini, tujuannya untuk membentuk kemandirian menggosok gigi di sekolah. Tahapan-tahapan yang lakukan antara lain: pertama tahap persiapan yaitu menyiapkan model penyimpanan sikat gigi dan media pembelajaran yang digunakan poster, serta phantom. Tahap kedua pelaksanaan yaitu memberikan stimulus berupa penyuluhan, simulasi dan praktik menggosok gigi secara konsisten selama 5 hari berturut-turut, dengan tujuan anak memiliki kemandirian menggosok gigi.

Berdasarkan uraian diatas, peneliti tertarik untuk membuktikan bahwa pemberian model 5Days gosgi dapat membentuk kemandirian menggosok gigi

(C) Poltekkes Kemenkes Jakarta I

Jl. Wijaya Kusuma No. 47-48 Cilandak Jakarta Selatan, Indonesia email: jurnalquality@poltekkesjakarta1.ac.id serta meningkatkan status kebersihan gigi pada anak usia dini di sekolah.

\section{Metode}

Metode yang digunakan dalam penelitian ini adalah quasy experiment dengan rancangan pre and post-test with one group design. Penelitian dilaksanakan pada bulan Februari 2020 pada lima Taman Kanak-Kanak di Wilayah Cilandak Jakarta Selatan yaitu: TK Pertiwi IV, TK Aisyiyah, TK Sekar Bangsa, TK Asih dan TK Kusuma Bangsa. Pemilihan tempat ini dilakukan karena pada sekolah tersebut belum memiliki program menggosok gigi secara rutin. Sampel penelitian diambil dengan teknik purvosive sampling, yaitu sebanyak 75 anak terdiri dari 15 anak tiap sekolah. Variabel independen pada penelitian ini adalah penerapan model 5Days Gosgi variabel dependen adalah kemandirian menggosok gigi dan status kebersihan gigi anak usia dini.

Pengumpulan data kemandirian menggosok gigi diukur ceklis menggosok gigi, telah dilakukan uji validitas dan reabilitas oleh peneliti sebelumnya yang sama meniliti kemandrian menggosok gigi (Ngatemi, 2020). Status kebersihan gigi diukur dengan standar pemeriksaan kebersihan gigi campuran yaitu indeks PHP-M (A'yun, 2018). Tahapan kegiatan sebagai berikut: pre-test dengan melakukan observasi menggosok gigi dan pemeriksaan status kebersihan gigi anak, kemudian dilakukan intervensi selama 5 hari berupa penyuluhan dan praktik menggosok gigi di sekolah setiap hari dan terakhir post-test dengan melakukan observasi menggosok gigi dan pemeriksaan status kebersihan gigi anak untuk melihat perubahannya. Data penelitian menggunakan skala rasio dan uji statistik, karena data tidak normal menggunakan uji wilcoxon.

\section{Hasil}

Hasil penelitian, menunjukkan bahwa responden dengan umur 5 tahun sebanyak 26 anak (34.7\%) dan umur 6 tahun sebanyak 49 anak ISSN 2655-2434

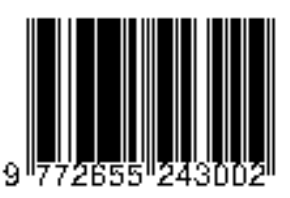


(65.3\%). Sedangkan responden jenis kelamin lakilaki sebanyak 31 anak (41.3\%) dan responden jenis kelamin perempuan sebanyak 44 orang (58.7\%). Hasil penelitian juga menunjukkan nilai rerata nilai kemandirian menggosok gigi anak mengalami peningkatan dari 4.47 menjadi 9.03. Nilai kebersihan gigi pada anak mengalami penurunan dari 33.99 menjadi 19.68 .

Tabel 1. Rerata nilai kemandirian menggosok gigi dan status kebersihan gigi

\begin{tabular}{ccccc}
\hline No & \multicolumn{1}{c}{ Variabel } & Mean & SD & Min-Max \\
\hline 1 & $\begin{array}{l}\text { Kemandirian } \\
\text { gosok gigi }\end{array}$ & & & \\
& Pre-test & 4.47 & 1.339 & $2-9$ \\
& Post-test & 9.03 & 1.052 & $7-10$ \\
2 & Status Kebersihan & & & \\
& Gigi & & & \\
& Pre-test & 33.99 & 9.189 & $18-59$ \\
& Post-test & 19.68 & 6.310 & $10-36$ \\
\hline
\end{tabular}

Selama 5 hari anak melakukan aktivitas menggosok gigi disekolah menunjukkan peningkatan kemandirian yang signifikan setiap harinya, terlihat pada grafik dibawah dari hari ke-1 mayoritas anak belum memiliki kemandirian dan hari ke-4 anak sudah dapat melakukan aktivitas menggosok gigi secara mandiri. Lebih jelasnya terlihat dalam grafik berikut:

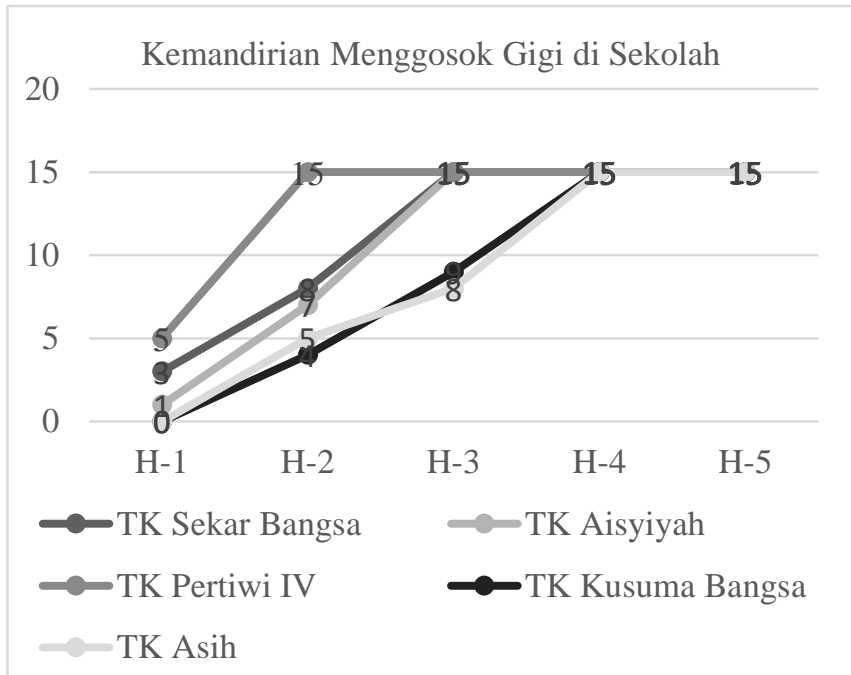

(C) Poltekkes Kemenkes Jakarta I

J1. Wijaya Kusuma No. 47-48 Cilandak Jakarta Selatan, Indonesia email: jurnalquality@poltekkesjakarta1.ac.id
Tabel 2. Uji normalitas data

\begin{tabular}{cccc}
\hline No & \multicolumn{1}{c}{ Variabel } & Pre-test & Post-test \\
\hline 1 & $\begin{array}{l}\text { Kemandirian gosok } \\
\text { gigi }\end{array}$ & 0.001 & 0.001 \\
2 & $\begin{array}{l}\text { Status kebersihan } \\
\text { gigi }\end{array}$ & 0.001 & 0.001 \\
\hline
\end{tabular}

* Komogrov-Smirnov

Tabel 3. menunjukkan hasil uji normalitas untuk kemandirian menggosok gigi anak dan status kebersihan gigi berdistribusi tidak normal sebab nilai p-value <0.05 sehingga dilakukan uji non parametrik.

Tabel 4. Uji efektifitas kemandirian menggosok gigi dan status kebersihan gigi sebelum dan setelah intervensi model 5Days gosgi.

\begin{tabular}{|c|c|c|c|}
\hline \multicolumn{2}{|c|}{ Variabel } & Mean \pm SD & $\mathrm{P}$-value \\
\hline \multirow{2}{*}{$\begin{array}{l}\text { Kemandirian gosok } \\
\text { gigi* }\end{array}$} & Pre-test & $4.47 \pm 1.339$ & \multirow{2}{*}{0.001} \\
\hline & Post-test & $9.03 \pm 1.052$ & \\
\hline \multirow{2}{*}{$\begin{array}{l}\text { Status kebersihan } \\
\text { gigi* }\end{array}$} & Pre-test & $33.99 \pm 9.189$ & \multirow{2}{*}{0.001} \\
\hline & Post-test & $19.68 \pm 6.310$ & \\
\hline
\end{tabular}

*Wilcoxon

Hasil uji efektifitas kemandirian menggosok gigi sebelum dan setelah diberikan perlakukan menunjukkan bahwa nilai p-value adalah 0.001 (p $<0,05$ ) artinya penerapan model 5days gosgi efektif meningkatkan kemandirian menggosok gigi anak usia dini di sekolah dan status kebersihan gigi pvalue adalah $0.001(\mathrm{p}<0,05)$ artinya penerapan model 5days gosgi efektif meningkatkan status kebersihan gigi dan mulut anak usia dini.

\section{Pembahasan}

Berdasarkan hasil penelitian, menunjukkan bahwa perbedaan kemandirian menggosok gigi sebelum dan sesudah inntervensi dengan nilai $\mathrm{p}$ value adalah 0.001 ( $\mathrm{p}<0.05)$, artinya penerapan model 5Days gosgi efektif membentuk kemandirian menggosok gigi anak usia dini di sekolah. Intervensi selama 5 hari efektif meningkatkan kemandirian menggosok gigi anak usia dini dikarenakan peneliti memberikan pendampingan

ISSN 2655-2434

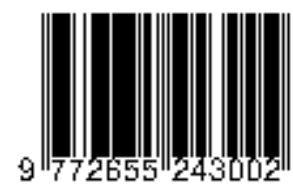


anak dalam proses pembelajaran menggosok giginya, anak terlibat langsung dalam cara menggosok gigi yang baik dan benar. Tahap pertama memberikan pengenalan peralatan menggosok gigi disertai tempat penyimpanannya yang disimpan di lingkungan sekolah. Respon sampel dalam mengawali lebih semangat dan antusias, artinya stimulus yang diberikan kepada anak berhasil terlihat kemampuan anak untuk mengambil dan menyimpannya peralatan menggosok gigi dengan mudahnya. Purnama (2019) menyatakan pemberian fasilitas model penyimpanan sikat gigi disekolah berupa sikat dan pasta gigi serta gelas kumur secara pribadi sehingga anak lebih mudah mengambil dan menyimpan sikat gigi tanpa bantuan orang lain.

Selanjutnya peneliti melakukan penyuluhan dan demonstrasi menggosok gigi menggunakan media phantom. Bagi anak, cara menyikat gigi perlu diberikan contoh suatu model yang baik serta dengan teknik yang sederhana mungkin. Penyampaian pendidikan kesehatan gigi dan mulut pada anak-anak harus dibuat semenarik mungkin, antara lain melalui penyuluhan yang atraktif tanpa mengurangi isi pendidikan, demonstrasi secara langsung. Pemilihan metode demonstrasi pada penyuluhan kesehatan gigi dan mulut mendukung meningkatnya pemahaman anak, dengan mempraktekkan secara langsung cara menyikat gigi yang benar (Ilyas, 2012). Selanjutnya responden melakukan latihan menggosok gigi setiap hari yang dilakukan 5 hari berturtut-turut, hal ini sejalan dengan Penelitian Pujiyasari (2015) metode latihan menggosok gigi selama 4 kali dapat meningkatkan kemandirian menggosok gigi. Diperkuat juga pernyataan Makuch (2011) bahwa metode latihan menggosok gigi dapat diterapkan untuk mengajarkan kemandirian anak prasekolah.

Keberhasilan ini juga dilihat peningkatan status kebersihan gigi dan mulut anak. Hasil uji efektifitas data berpasangan menunjukkan bahwa

(C) Poltekkes Kemenkes Jakarta I

J1. Wijaya Kusuma No. 47-48 Cilandak Jakarta Selatan, Indonesia email: jurnalquality@poltekkesjakarta1.ac.id nilai $p$-value adalah $0.001 \quad(\mathrm{p}<0.05)$ artinya penerapan model 5Days gosgi efektif meningkatkan status kebersihan gigi dan mulut anak usia dini. Skor kebersihan gigi anak usia dini mengalami peningkatan karena sampel telah diajarkan dan memahami praktik menggosok gigi yang benar sehingga pada hari ke-4 semua anak sudah dapat melakukan praktik menggosok gigi secara mandiri. Praktik menggosok gigi yang benar akan dapat menghilangkan plak. Penelitian Purnama dkk (2019), membuktikan bahwa menggosok gigi dengan teknik yang benar akan meningkatkan keterampilan menggosok gigi dan kebersihan gigi dan mulutnya. Diperkuat juga pendapat Arianto (2012) menyatakan menggosok gigi merupakan cara mekanis untuk membersihkan plak. Menggosok gigi bertujuan untuk membersihkan deposit lunak pada permukaan gigi dan gusi dan merupakan tindakan preventif dalam menuju keberhasilan dan kesehatan rongga mulut yang optimal.

\section{Kesimpulan dan Saran}

Berdasarkan hasil penelitian, dapat disimpulkan bahwa:

1. Penerapan model 5Days gosgi terbukti secara signifikan $(\mathrm{p}<0.001)$ efektif meningkatkan kemandirian menggosok gigi anak usia dini di sekolah.

2. Penerapan model 5Days gosgi terbukti secara signifikan $(\mathrm{p}<0.001)$ efektif meningkatkan status kebersihan gigi dan mulut anak usia dini.

\section{Daftar Pustaka}

Alhamda S. (2011). Status kebersihan gigi dan mulut dengan status karies gigi (kajian pada murid kelompok umur 12 tahun di sekolah dasar negeri kota bukittinggi). Berita Kedokteran Masyarakat,27(2):108-15. https://doi.org/10.22 146/bkm.3411
ISSN 2655-2434

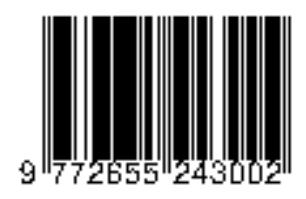


Arianto A, Shaluhiyah Z, Nugraha J. (2014). Perilaku Menggosok Gigi pada Siswa Sekolah Dasar Kelas V dan VI di Kecamatan Sumberejo. Jurnal Promosi Kesehatan Indonesia, 9(2):127135. https://doi.org/10.14710/jpki.9.2.127-135

Arum A. (2016). Pelatihan Menggosok Gigi Untuk Meningkatkan Kemampuan Bina Diri Anak Tunagrahita Sedang di SLB. Jurnal Pendidikan Khusus, 9(1).

A'yun Q, Subekti A. (2018). Effect of A'yun's predictor software on the behavior, saliva $\mathrm{pH}$, and PHPM index. Majalah Kedokteran Gigi Indonesia, 4(2):89-94. https://doi.org/10.22146 /majkedgiind.23722

Dogar F, Kruger E, Dyson K, Tennant M. (2011) Oral health of pre-school children in rural and remote Western Australia. Journal Rural Remote Health, 11(4):1869.

Ilyas M, Putri I. (2012). Efek penyuluhan metode demonstrasi menyikat gigi terhadap penurunan indeks plak gigi pada murid sekolah dasar. Dentofasial, 11(2):91-95.

Kemenkes RI. (2012). Pedoman Usaha Kesehatan Gigi Sekolah (UKGS). Jakarta, Direktorat Jenderal Bina Upaya Kesehatan.

Kemenkes RI. (2018). Hasil Utama Riskesdas 2018. Badan Penelitian dan Pengembangan Kesehatan.

Makuch A, Rescke K, Rupf S. (2011). Effective Teaching of Tooth Brushing to Preschool children. J Dent Child (Chic), 78(1):9-12.

Martani W. (2012). Metode Stimulasi Dan Perkembangan Emosi Anak Usia Dini. Jurnal Psikologi, 39(1):112-200. http://doi:10.22146/ jpsi.6970.

Ngatemi, Purnama T. (2020). Dental Health Handbook as Parents Monitoring in the Formation of Independence for Brushing Teeth in Early Childhood. Indian Journal of Public Health Research Development, 11(1):785-790

Notohartojo IT, Lely S. (2011). Nilai Karies Gigi pada Karyawan Kawasan Industri di Pulo Gadung Jakarta. Media Penelitian dan Pengembangan Kesehatan, 21(4).

Nuraini N, Khusnal E. (2015). Pengaruh Penyuluhan Kesehatan Melalui Audio Visual terhadap Kemandirian Gosok Gigi pada Anak Prasekolah di TK ABA Tegalsari Yogyakarta: STIKES'Aisyiyah Yogyakarta

(C) Poltekkes Kemenkes Jakarta I

Jl. Wijaya Kusuma No. 47-48 Cilandak Jakarta Selatan, Indonesia email: jurnalquality@poltekkesjakarta1.ac.id
Santoso Bedjo, Gejir Nyoman, Fatmasari D. (2017). Information System Monitoring Model Implemented in School Health Dental Unit. ARC Journal of Dental Science, 2(4), 8-11. http://dx.doi.org/10.20431/2456-0030.0204003

Sosiawan A, Heroesoebekti R, Hapsoro A, Santosa L. (2015). Gambaran Tingkat Keparahan Karies Gigi Pada Ibu-ibu Usia 36-45 Tahun Dusun Claket Desa Claket Kecamatan Pacet Kabupaten Mojokerto Pada Bulan April 2016, 6(2):1-12.

Pujiyasari S, Asih S, Nurullita U. (2014). Pengaruh metode latihan menggosok gigi dengan kemandirian menggosok gigi anak retardasi mental usia sekolah. Jurnal Keperawatan dan Kebidanan (JIKK), 3:1-11

Pullishery F, Panchmal GS, Shenoy. (2013). Parental attitudes and tooth brushing habits in preschool children in Mangalore, Karnataka: A cross-sectional study. International Journal of Clinical Pediatric Dentistry, 6(3), 156-160. http://doi:10.5005/jp-journals-10005-1210

Purnama T, Rasipin R, Santoso B. (2019). Pengaruh Pelatihan Tedi's Behavior Change Model pada Guru dan Orang Tua terhadap Keterampilan Menggosok Gigi Anak Prasekolah. Jurnal Quality Kesehatan, 13(2):75-81. https://doi.org/10.36082/qjk.v13i2.80

Purnama T, Rasipin, Santoso B. (2019). Model Tedi's behavior change model sebagai upaya pembentukan perilaku menggosok gigi anak prasekolah: Program Magister Terapan Kesehatan Poltekkes Semarang
ISSN 2655-2434

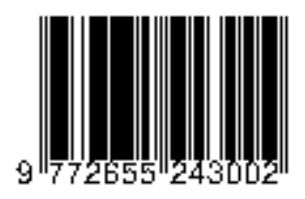

